\title{
Az avar kori vasmüvesség munkafolyamatai, korabeli mesterségei
}

\author{
'GALLINA ZSOLT - 2TÖRÖK BÉLA \\ 'Ásatárs Kft, H-6000 Kecskemét, Futár u. 12., e-mail: gallinazsolt@gmail.com \\ ${ }^{2}$ Miskolci Egyetem, Metallurgiai Intézet, H-3515 Miskolc-Egyetemváros, e-mail: bela.torok@uni-miskolc.hu
}

GALLINA, Zs. - TöRÖK, B.: The smith's craft and the work processes of Avar-period ironworking

Abstract: Discussed here are the basic work phases of Avar-period ironworking alongside the smith's craft. We offer an overview of the period's smelting procedures and the salient traits of the smith's craft. Next, we seek an answer to questions of "who?", "what?", "where?" and "how?", in the hope of mapping how this craft was practiced by looking also at the archaeological, experimental archaeological, archaeometric, historic and ethnographic aspects of smithing. We expect to gain conclusive answers to our questions following the meticulous assessment of the evidence on Avar-period ironworking and the reconstruction of its processes.

Keywords: Avar-period ironworking, smelting, bloom production, smith, differentiation, ironworking society

\section{Bevezetés és a tanulmány célja}

Az elmúlt évtizedekben a Kárpát-medence területén az avar és a honfoglalás kor fémművességéhez ka pcsolhatóan számos régészeti lelőhely és lelet került napvilágra. Az iparrégészet eredményessége pedig az ezredforduló óta újabb lendületet vett.

A kutatandó téma aktualitása abban rejlik, hogy a kétkezi, de mégis nagy tudást igénylő szakmáknak manapság igencsak megkopott a becsülete, és érdemes lenne ezeket feleleveníteni, mielőtt örökre a múlt ködébe vesznek. A kora középkori vasművesség, melyben két szakma (kohász, kovács) egyesült, ahol együtt járt a nehéz és összetett kézi munka, valamint a nagyfokú, empirikus úton szerzett, mesterről mesterre szálló szaktudás. Erő, tudás és mágia-gyakorlat, állandóság és változás, hajlam a megújulásra (manapság divatos szóval innovációra). Nem véletlen, hogy a korabeli ember számára a vasat művelő ember teremtő erővel bírt, démiurgoszként már-már isteni hatalommal, legalábbis különös gyógyító erővel ruházták fel.

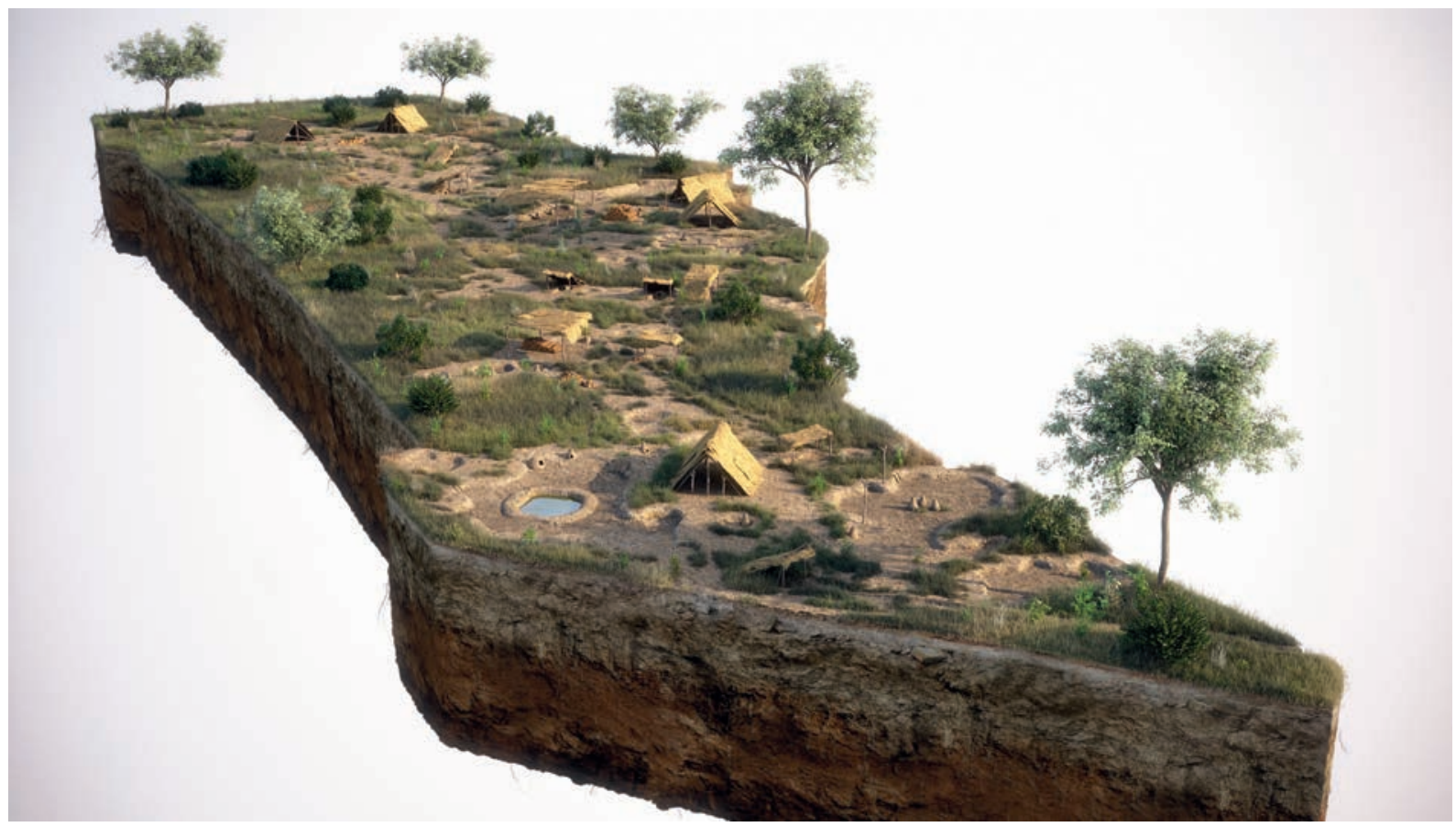

1. ábra. A kaposvári kohótelep 3D-s távlati rekonstrukciója (Készítette: Pazirik Kft. Gallina Zsolt instrukciói alapján) 
Eddig kevéssé ismertek a kora középkori vasművesség elsajátításának, művelésének, változásainak, átadásának módjai. Nem tudjuk, hogy egy-egy avar kori közösség mindezeket hogyan, milyen közösségi keretek (múhely, mesterség, mint szakma) között szervezte. Ehhez szeretnénk most saját kutatásainkkal hozzájárulni.

Célunk a korabeli vasmúvesség szakmai rendszerének, elsősorban a kovácsmesterség magas társadalmi presztízsének, elsajátításának, munkamódszereinek megvilágítása, az avar vasműves települések társadalmának, a szakma differenciálódásának vázlatos bemutatása.

\section{Az avar kori vasgyártás (kohászat) fázisai a régészeti források, a kísérleti régészet és archeometriai ku- tatások tükrében}

A kohótelepeken megfigyelt fázisok által rekonstruálhatjuk a kohász szakma gyakorlásának folyamatát is (1. ábra). Az alábbiakban a vasgyártás menetét általánosságban mutatjuk be, a kaposvári, valamint a zamárdi lelőhelyeken megfigyelt érdekesebb jelenségek említésével.

A korábbiakban megismert eljárásokat ki lehet, és ki is kell próbálni a gyakorlatban ahhoz, hogy minél teljesebb képet kaphassunk az egykori vasművességről, főleg annak kohászati részéről. Az avar kori vasművesség szakmai komplexitásának vizsgálata a bevezető, előkészítő tevékenységekkel (faszénégetés, ércpörkölés, kemenceépítés és -kiégetés), a kísérleti bucavas-kohászattal, illetve a fémalakító (bucatömörítés és kovácsolás) tevékenységek reprodukálásával lesz teljes. Mindezeken keresztül tudjuk a szakma művelésének, átadásának folyamatát a gyakorlati szempontból leginkább vizsgálni.

Az 1962-64-es diósgyőri és 1992-es soproni ${ }^{3}$ próbaolvasztások voltak az úttörő jellegű vaskohászati rekonstrukciós kísérletek hazánkban. Ezt követően, az elmúlt évtizedben számos hazai (Ómassa, Somogyfajsz) és nemzetközi esemény keretében (Iron Smelting Days: 2010 Alphen an den Rijn (Hollandia), 2013 Solms (Németország), több alkalommal Adamov (Csehország)) végeztünk kísérleti régészeti, rekonstrukciós jellegű próbakohósításokat. ${ }^{4}$ 2012-ben Zamárdiban, 2016-ban pedig Kaposvár-Fészerlakon, az avar kori kohótelepek feltárt műhelygödreiben eredményes próbakohósításokat végeztünk. A feltárások, valamint az ugyanazon műhelygödörben végrehajtott, archeometriai mérésekkel alátámasztott és fontos, interdiszciplináris kérdésekre válaszokat adó kísérleti kohósítások együttese egyedülállónak számít egész Európában (2-3. ábra). ${ }^{5}$

A régészeti, néprajzi adatok és a kísérleti régészeti tapasztalatok alapján a következőkben összegezhetjük az avar kori vasgyártás (kohászat) folyamatát. A kohászatot többféle, egymásra épülő tevékenység előzte meg. Az alapanyagként szolgáló gyepvasércet bányászták, pontosabban felszíni vagy felszín-közeli ércgyűjtést végeztek. Az eddigi tapasztalatok is azt mutatják, hogy a kohótelepek gyepvasérc-lelőhelyhez és vízhez közeli területeken találhatóak. Az ércgyűjtéshez nagy szakértelem kellett, ugyanis a kohász tudta a legjobban, hogy milyen szí-

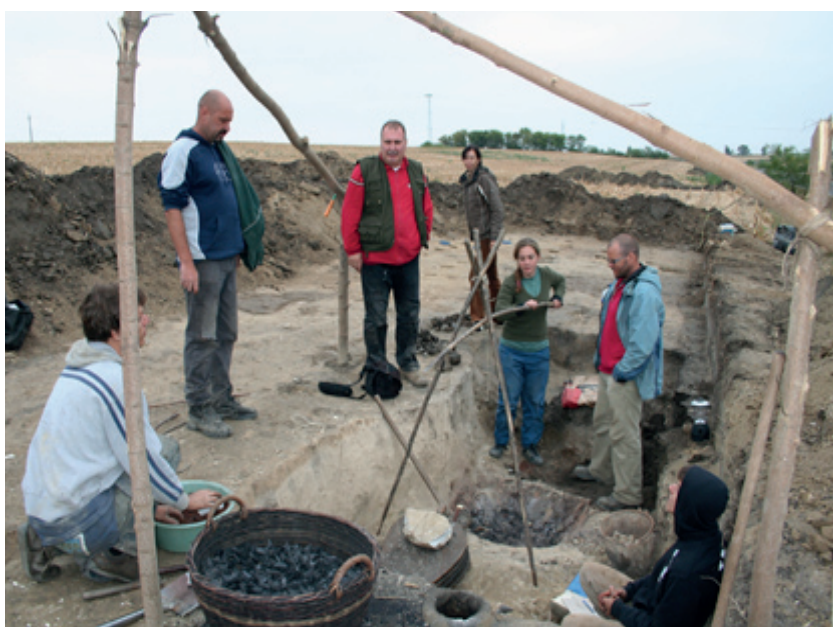

2. ábra. Kísérleti kohófújtatás Zamárdiból 2012-ben (Fotó: Móricz Róbert)

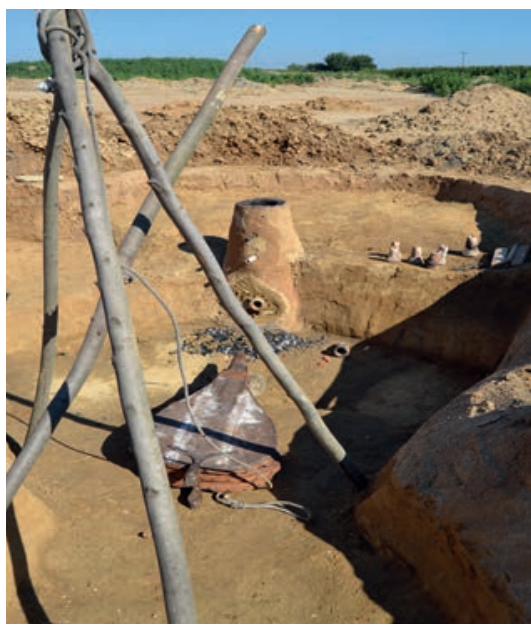

3. ábra. Kísérleti vaskohó Kaposváron 2016-ban (Fotó: Gallina Zsolt)

1 A téma átfogó kutatása zajlik az „Avar kori vasművesség az interdiszciplináris kutatások tükrében” című NKFI (OTKA K) projekt keretei között a Miskolci Egyetemen és más, kapcsolódó kutatási helyszínen, amelynek a szerzők is részesei. A publikáció elkészítése, illetve az ahhoz szükséges kutatás a Nemzeti Kutatási, Fejlesztési és Innovációs Hivatal támogatásával történt (NKFIH K 116396 nyilvántartási számú támogatási szerződés, illetve kutatási program).

2 HeCKenAst et al. 1968, 195, 232.

3 GöMÖRI 2000a, 275-277.

4 Dr. Török Béla kohómérnök, archeometallurgus és történelemtanár, Thiele Ádám gépészmérnök, kovács és kísérleti régészeti szakértő, Dr. Gömöri János régész szakértő, Dr. Fehér András kohómérnök, Gallina Zsolt régész szakértő, Dr. Költő László régész szakértő részvételével.

5 2012-ben a Nemzeti Kulturális Alap, 2016-ban az OTKA támogatásával. 
nü, keménységú, struktúrájú anyag a legalkalmasabb kohósításra. ${ }^{6}$ Az érc, a szükséges fa és egyéb segédanyagok, eszközök szállitását, a faszén elkészítését, darabolását feltehetően mások végezhették.

A teljes szakmai vertikum bemutatásához jó támpont a kaposvári és a zamárdi lelőhely, ahol az avar kohótelepeken végbemenő kohászati munkafázisok nagy részét meg lehetett figyelni az ércpörköléstől a kovácsolásig.

Azáltalános gyakorlat szerint, az érclelőhelyek, érctelepek közelében történhetett a vasérc kézi válogatása, osztályozása, mosása, szárítása. A darabolást már a kohóknál végezték, amelynek tapasztalatból eredő célja, hogy a redukáló gázok minél nagyobb felületen érintkezhessenek a bucakemencébe adagolt ércdarabokkal. A feldarabolt, vasércdarabkákategynyitottgödörbenfaszénnelvagyfávalmegpörkölték. Azeljárássoránavasércelveszítifizikailag és kémiailag megkötött víztartalmát, egyben elöredukált állapotba kerül. ${ }^{7}$ A vasérc pörkölését 1-2,5 méter hosszú, ovális alakú, alján vörösre, oldalt szürkére égett, teknő alakú gödrökben végezték, majd esetleg tovább darabolták.

A kohósításhoz a vasércen kívül faszénre is szükség van. Ezt ún. faszénégető boksákban állították elő, amelyek 2-3 méter átmérőjū, 20-35 centiméter mély, tányér alakú mélyedések. Az említett telepeken sajnos erre utaló nyomot nem találtunk. E sekély objektumok vagy elpusztultak, vagy a lelőhely általunk fel nem tárt, a nyomvonalon kívül levő részén helyezkedhettek el. ${ }^{8} \mathrm{~A}$ kohósítás előkészitését; az érc pörkölését, a mühelygödör kialakítását, a kohók elkészítését, szikkasztását két nap alatt véghezvitte a kohászmester és két-három segédje.

A kohósítást legalább félig vagy nagyobbrészt földbe mélyített kohókban végezték (4. ábra). ${ }^{9}$ Ezek csonkakúp alakú, agyagból felépített, zömök, kissé földbe mélyített objektumok, amelyek kisebb, kerekded salaklecsapoló gödrökkel rendelkeztek. Az eredetileg 70-90 centiméter magas kohókat megformázásuk után fával szikkasztották és faszénnel feltöltve előfütötték (5. ábra). Ezután a toroknyíláson több adagban helyezték be a faszenet és a megpörkölt vasércet. A kemence elől levő nyílását ún. mellfalazattal fedték be. A mellfalazatba fúvócsövet helyeztek. A fúvócsövön keresztül kézi fújtatással huzamosabb ideig maximum $1200-1350{ }^{\circ} \mathrm{C}$ hőmérsékletet értek el a kohó medencéjében. A mellfalazatok és fúvócsövek minden kohósítás alkalmával cserélődtek. Ezekből, és az előkerült vassalakból következtethetünk az előállított vas mennyiségére, így a kohótelep nagyságára és az ott folyó termelés intenzitására. ${ }^{10} \mathrm{~A}$ vasművességgel kapcsolatba hozható lelőhelyeken talált salakok jellege (folyósalak, kemencesalak, illetve később bucatömörítés salakja és kovácssalak) alapján archeometriai vizsgálatok által lehet következtetni az alkalmazott technológiára és annak jellegzetességeire. ${ }^{11}$

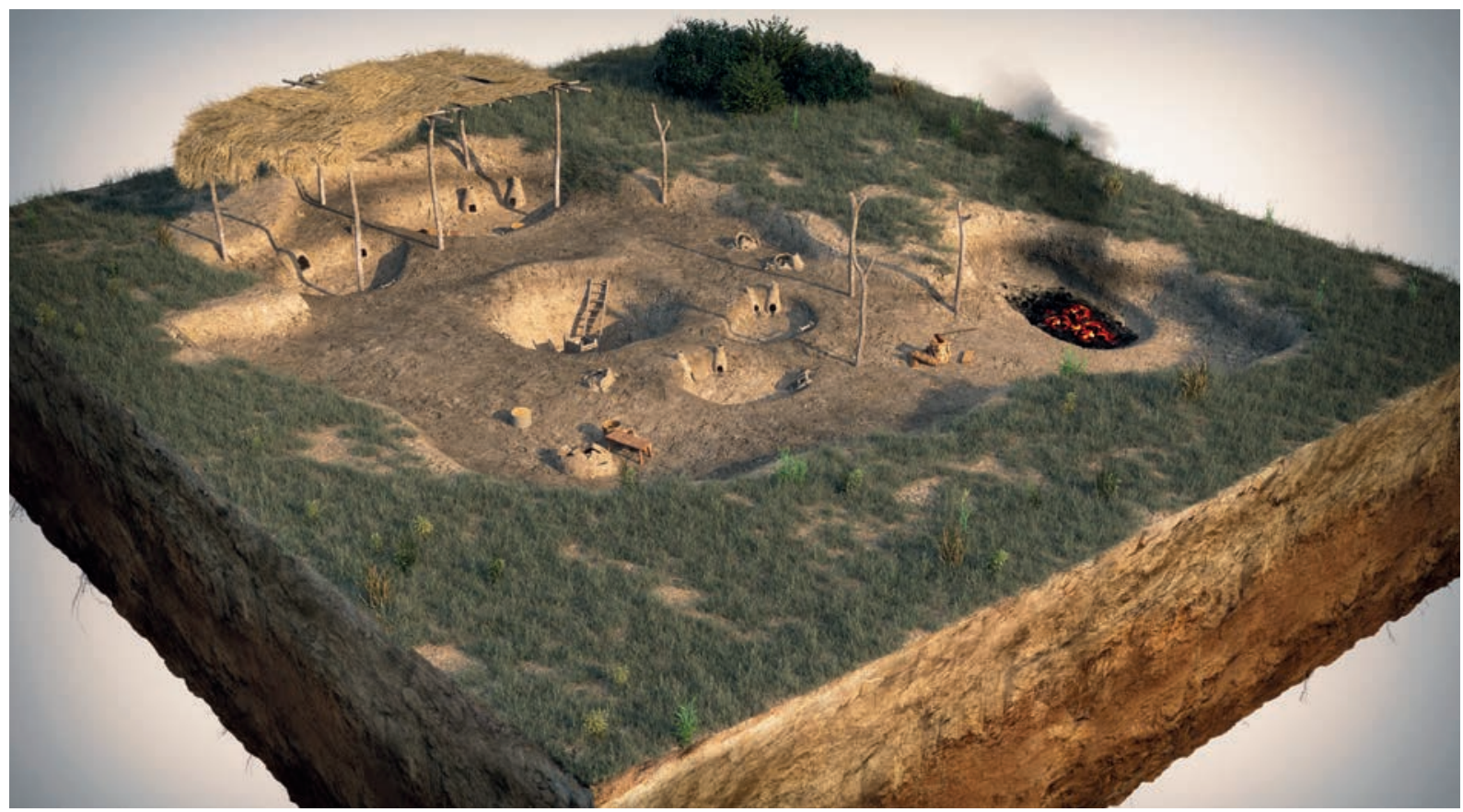

4. ábra. A kaposvári kohótelep egyik mühelyének 3D-s rekonstrukciója (Készítette: Pazirik Kft Gallina Zsolt instrukciói alapján)

6 TÖRÖK 2011, 15-16.

7 TöRÖK 1999, 160; ТӧRÖK 2011, 15.

8 GömÖRI 2000a, 257-268.

9 A zamárdi és kaposvári kohótelep tapasztalatai alapján sejtettük, hogy az erős lepusztultság miatt maradt meg csak a kohók alja, de Bátaszéken bizonyosságot is nyert, az ideális körülmények (nem pusztult le a korabeli felszín) és a szakszerű feltárás folytán (CzövEK, 2010, 213-241), hogy az avar kohókat is nagyrészt a földbe mélyítették.

10 GÖMÖRI 2000a, 268.

11 TÖRÖK - GALLINA - KovÁCS 2015, 232-233. 


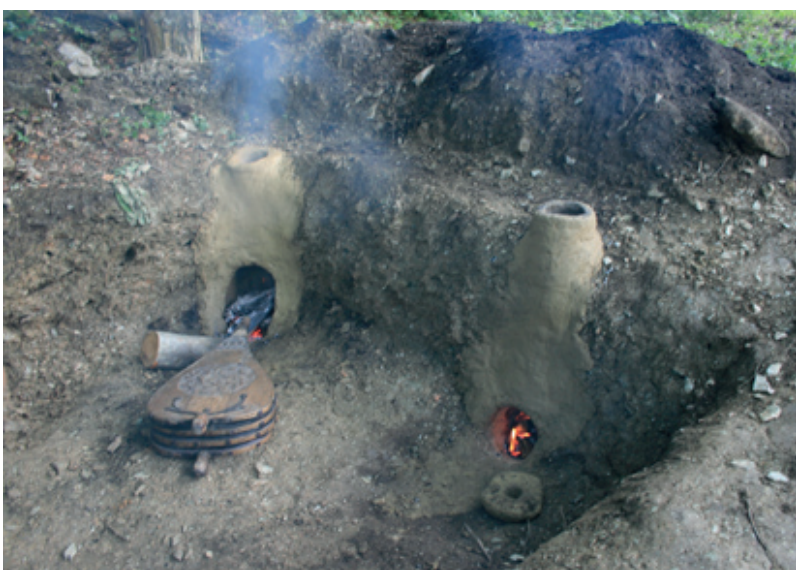

5. ábra. Kohók szikkasztása

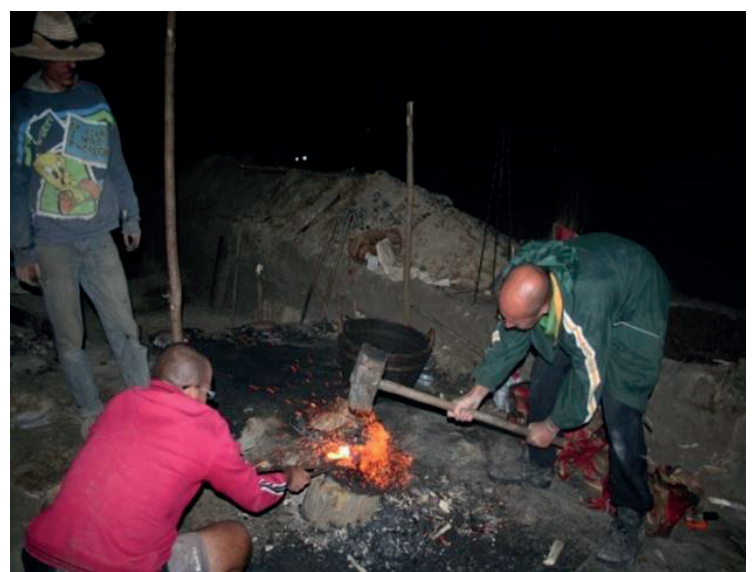

6. ábra. Bucatömörítés Zamárdiban (2012) (kísérleti bucavaskohászat, Ómassa, 2010)

A kohósítást ideálisan három-négy ember tudja elvégezni, egyikük (mester) irányításával. A kohósítás folyamata, az előfütés, adagolás, fújtatás (öt-nyolc óra), tömörítés összesen fél nap alatt megtörtént. ${ }^{12}$ Rendkívül nehéz és fárasztó munkának számított a kézi erővel történő fújtatás, amit váltásban lehetett csak elvégezni. A kemence előtti sekély mélyedésben mindig található kifolyt salak, ami fontos információt jelentett a kohász számára az olvasztás állapotáról. ${ }^{13} \mathrm{~A}$ kohósítás hatásfoka, vaskihozatala alacsony volt. Kísérleti régészeti adatok bizonyítják, hogy egy kohósítással átlagosan 15-20 kilogramm faszén felhasználásával és 10-15 kilogramm előpörkölt érc adagolásával 1-2,5 kilogramm jó minőségű bucavasat nyerhettek, és egy kemence átlagosan mintegy tíz olvasztást bírhatott ki jelentősebb átépítés nélkül. ${ }^{14}$ Természetesen ez utóbbi nagyban függött a bucakemence múhelyfalba történt beépítettségétől és a kohósítások folyamatosságától is.

Minden kétséget kizáróan avar vaskohászok által készített buca eddig alig került elő Magyarországon, viszont a 2003-ban, Lábod-Petesmalom lelőhelyen előkerült, 9,5 kilogramm súlyú, 25-26 centiméteres átmérőjü, ún. ékelt vasbuca környezetében talált salakdarabok és finom kivitelezésű, tölcséres fúvókák töredékei avar kori vaskohászati mühelyekre engednek következtetni. ${ }^{15}$

A kemencéből fogókkal kihúzott bucavasat még meleg állapotban egy helyi tǔzhelyen újraizzították, majd kalapálva tömörítették és szabadították meg a felesleges salaktól (6. ábra). ${ }^{16}$ Zamárdiban és Kaposváron is egy ízben meg tudtuk figyelni, hogy a kohó és az újraizzító tűzhely egymás közvetlen közelében, funkcionálisan összetartozva helyezkedett el, s egy tetőzet alatt ment végbe (7. ábra). ${ }^{17} \mathrm{Az}$ újraizzító túzhelyek kerek, 40-50 centiméter külső átmérőjű, kissé lemélyített gödrök. ${ }^{18}$

Egy-egy kohótelepet igen hosszú ideig, akár évtizedekig is használhattak, több periódusban, egyszerre két-három kohót üzemeltetve, azaz egy kohótelepen legfeljebb két vagy három csapat dolgozott egyszerre. ${ }^{19}$ Minden évben új kohókat kellett építeni, mivel a téli időjárás viszontagságai, a fagyok minden bizonnyal tönkretették az agyagépítményeket, amelyek felett

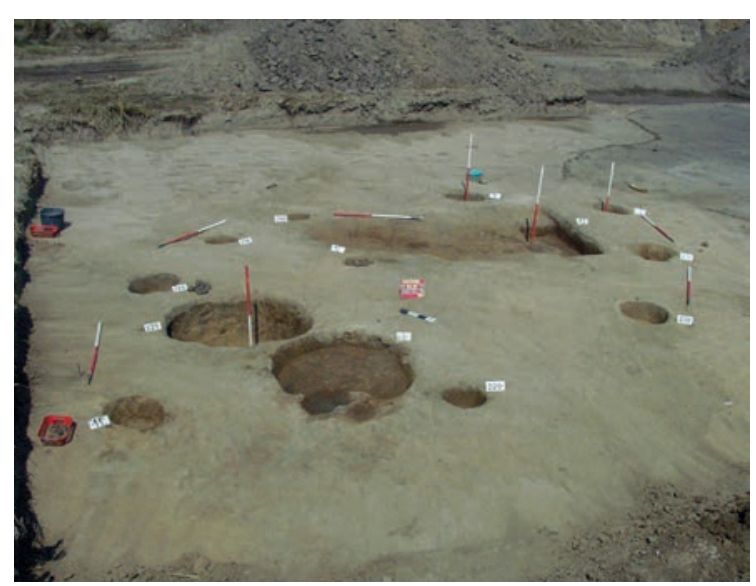

7. ábra. Kohó és újraizzító együttese egy tetőzet alatt Kaposváron (Fotó: Gallina Zsolt)

12 E fázisokat Agricola is részletesen leírja, a fújtatást a korai középkorinál nagyobb belső térfogatú kemencében 8-12 órára teszi, továbbá beszél a salakcsapolásról és a tömörítésröl is (AGRICOLA 428-429).

13 TÖ̈ÖK 2011, 18

14 TÖRÖK 2011, 25; TÖRÖK - GALLINA - KovÁcs 2015, 236.

15 A szokatlanul nagy vasbucát Költő László bocsátotta rendelkezésünkre. Metallográfiai vizsgálata heterogén szövetszerkezetet mutatott, helyenként igen nagy foszfortartalommal (TöRÖK ET AL. 2018.).

16 Тӧвӧк 2011, 17.

17 Galuina 2002, 78, 5. kép; Galuina - Hornok - Somogyi 2007, 160; Gallina 2011, 180, 9. kép.

18 GÖMÖRI 2000a, 257-269.

19 A kohótelepek éppen emiatt a folyamatos megújítás miatt akár hatalmas méretúek is lehetnek, egy-két emberöltő alatt igen távol kerülhettek eredeti helyüktöl (HECKENAST 1966, 144). Kiváló példa erre a bemutatott Kaposvár-Fészerlak és Zamárdi esete. 
legfeljebb hevenyészett, ideiglenes tető lehetett. Mint látjuk, több, erre a célra szerveződött ember, együttes munkájára volt szükség, akik a tevékenység jellegéből adódóan férfiak voltak. ${ }^{20}$

A kohászati tevékenységhez tartozik még a fentieken kívül néhány "kiegészítő" jellegű objektum is. Az egyik típus az agyagnyerő gödör, amely arra szolgált, hogy a belőle kivájt agyagból készítették a kohókat, a mellfalazatokat és a fúvócsöveket. Ezen kívül számos tárológödör, és Kaposváron összetett faszerkezetű kút is megemlíthető. A korabeli kohászok helybeli élelmezését biztosították még továbbá a különböző típusú (kenyérsütő, füstölő) szabadtéri kemencék. A felsorolt munkafázisokra összefoglalóan elmondható, hogy teljesen tipikusak, vagyis nem csak a kaposvári és a zamárdi, hanem az összes avar kori kohótelepen hasonló módszerekkel dolgoztak, kisebb eltérésekkel, más hangsúlyokkal (8. ábra). ${ }^{21}$

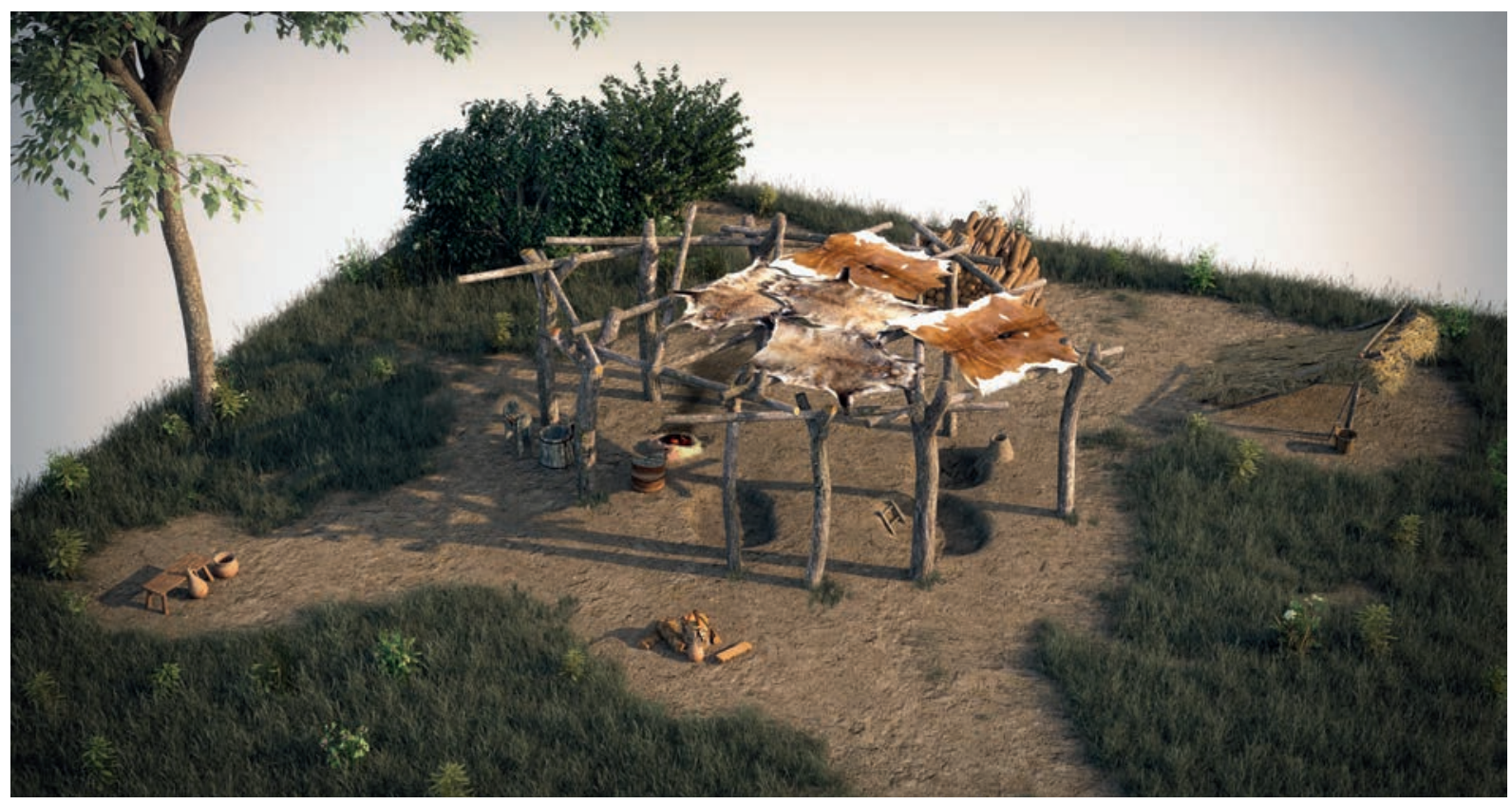

8. ábra. A kaposvári kohó-újraizzító együttes tetőzetének 3D-s rekonstrukciója

(Készitette: Pazirik Kft. Gallina Zsolt instrukciói alapján)

\section{Az avar kori kovácsok szakmai vonásainak összefoglalása a régészeti források, a kísérleti régészet és az archeometriai eredmények alapján}

Az alábbiakban komplex kutatásaink alapján igyekszünk vázlatot adni az avarok vasfeldolgozásának, a kovács szakmának technológiai vonásairól. A tömörített vasbuca a kovácsmühelybe került, ahol félkész-, vagy végtermékké dolgozták fel. Jelenleg viszonylag kevés avar kori kovácsmühelyt ismerünk. Kis számuknak és bizonytalan eredetüknek egyik oka az, hogy ezek inkább felszíni, cölöpszerkezetes építmények lehettek és könnyebben elpusztulhattak ${ }^{22}$ bár néhol megjelent a félig földbemélyített változatuk is. ${ }^{23}$ Zamárdiban egy biztos, kovácstűzhellyel rendelkező, erősen a földbe mélyített kovácsmúhely alapgödre is előkerült (9. ábra). ${ }^{24}$

Említésre érdemes, hogy a kézirat leadásakor tártak fel egy földbe mélyített, késő avar kovácsmühelyt Kecskemét északi határában, benne kovácstűzhellyel, az üllő helyével, kovácssalakokkal. ${ }^{25}$

László Gyula a kovácsmủhelyek berendezését és technológiáját, az avar kori leleteknek az Altaj vidéke vasés fémművességével való rokonítása kapcsán, alapvetően azokhoz hasonlónak képzelte el. A múhely kovácstűzhelye köré mintegy 30-35 centiméter magas, U alakú agyagfalat építettek, amelynek közepén késpengényi vékony rést hagytak, amely mögött volt a kovácsfújtató. A keskeny rés funkciója az volt, hogy mögötte csak vékony vonalnyi faszén kezd izzani, így a rés egyfajta hőfúvókaként működik és igen aprólékos munka elvég-

20 BARTHA 1958, 320.

21 Gallina 2002, 77-80; Gallina - HornoK - Somogy 2007, 153-168.

22 Például: Nemeskér, Iván, Dénesfa (GöMÖRI 2000a, 278.)

23 GömöRI 2000a, 278.

24 Ebből a szempontból igen érdekes az a zamárdi temetőből származó 4 sír, ahol fémmegmunkáló szerszámok kerültek elő (ÓDoR - RÁcz 2011, 249).

25 Wilhelm Gábor és Gallina Zsolt feltárása. 
zésére is alkalmas, egy-egy pontra irányítható hőimpulzust szolgáltat. Az agyagfal túloldalán a kovácstűzhely fenekét faszén borította, a kovács izzításra kizárólag ezt a tüzelőanyagot használta (10-11.ábra). ${ }^{26}$

A tömörített félkésztermék kovácsolása másfajta szakmai tudást igényelt, mint a kohósítás, illetve bucatömörítés. A kovács alapanyaga alacsony széntartalmú, de karbonban heterogén szövetszerkezetü, ötvözetlen bucavas volt. Ebből kellett a kovácsnak a faszenes hevítés és hűtés gyakoriságának, mértékének, illetve a kalapálás erősségének, jellegének megválasztásával, változtatásával a szándéknak, megrendelésnek megfelelő tárgyat készíteni.

Zamárdi és Kaposvár avar kori vaskohászati lelőhelyeiről az elmúlt években számos vastárgy leletet megvizsgáltunk. A vizsgálatokra úgy vá-

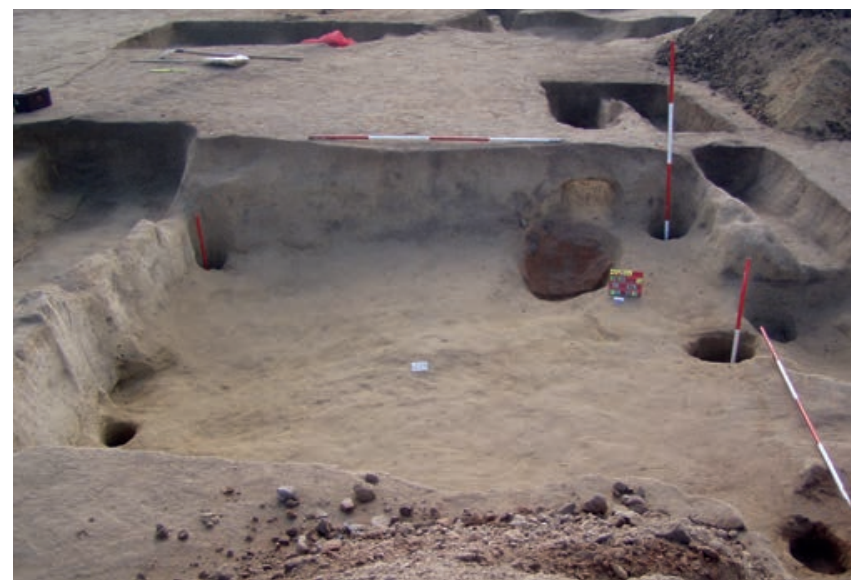

9. ábra. Avar kovácsmühely Zamárdiból (Fotó: Gallina Zsolt) logattuk ki a tárgyakat, hogy az mind az eszközök formáját, jellemző anyagvastagságát, illetve a felhasználás jellegét is a lehető legteljesebb spektrumban képviseljék. Így késeken, szögeken, hajtükön, ásópapucson, láncszemeken és egyéb beazonosítható és be nem azonosítható funkciójú vastárgyon végeztünk mikroszkópos metallográfiai vizsgálatokat. ${ }^{27} \mathrm{Az}$ itteni tapasztalatainkat egészítik ki Előszállás és Úrhida avar kori lelőhelyein talált vasfokosok anyagszerkezetének az alkalmazott technológia fókuszából végzett vizsgálatai. ${ }^{28}$

Az anyagvizsgálatok alapján elmondható, hogy az avar kovácsok tudatosan, többféle kovácsolási stratégia, alakítási módszer közül választottak. Találtunk példát arra, hogy egy darab tömörített vasbucából, hajtogatás, rétegezés nélkül, „szabadkovácsolással” készítették el a tárgyat, amelynek szegélye, éle (ásópapucsnál, néhány késnél) többször átkovácsolt, nagyobb karbontartalmú anyag volt.

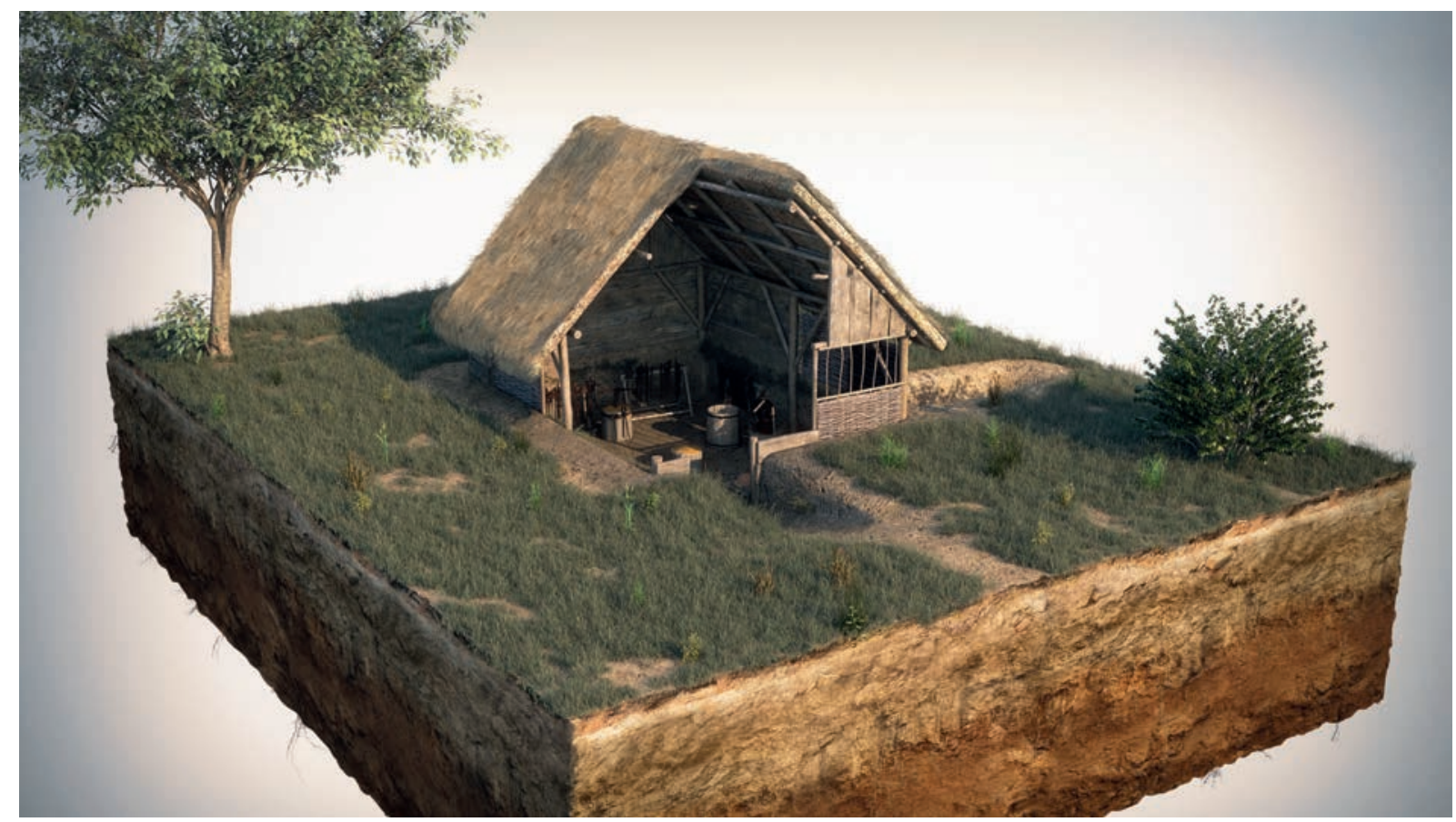

10. ábra. A zamárdi kovácsmühely 3D-s rekonstrukciója - távoli (Készítette: Pazirik Kft. Gallina Zsolt instrukciói alapján)

26 LÁsZló 1997, 264-265.

27 TÖRÖK - KovÁCs 2009; TÖRÖK - Kovács 2011; TÖRÖK - Gallina - KovÁCs 2015, 234-235; BARKócZY et Al. 2017.

28 TÖRÖK - KOVÁCS - SZÜCSI 2016. 


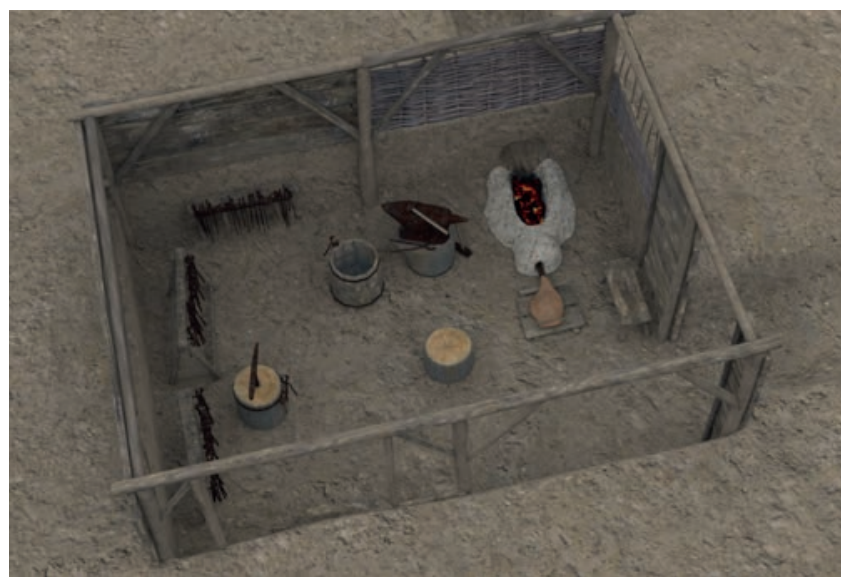

11. ábra. A zamárdi kovácsmühely 3D-s rekonstrukciója - közeli (Készítette: Pazirik Kft. Gallina Zsolt instrukciói alapján)
A vizsgált avar vastárgyak többségénél azonban vagy határozott réteges szerkezet mutatkozott, vagy a zárványok és a karbonban dúsabb sávok elhelyezkedése alapján egyfajta hajtogatás (pl. fokosnál, baltánál) volt feltételezhető. A réteges szerkezetű anyag esetén - egyes tárgyak, főként kések metszetében 5-8 igen vékony réteg is felfedezhető - az egyes rétegek a karbontartalmukban térnek határozottan el egymástól. Ezeket a rétegeket magas hőmérsékleten, közepes erővel kovácsolták össze, megfelelő szilárdságú eszközt készítve így. A karbonban gazdagabb éleket jobban megdolgozták. A tárgyat a készítés alkalmával többször is újrahevítették,majd szabad levegőn hült le.

Főként vékonyabb keresztmetszetű tárgyak esetén előfordult, hogy a tárgyat gyorsabban hútötték le a levegőn és nem izzították újra. Nagyon kemény (martenzites) szövetet eredményező hirtelen vízbemártást viszont a jelek szerint nem alkalmaztak, illetve szándékos, utólagos hőkezelés
nyomait sem találtuk, de meg kell jegyeznünk, hogy Zamárdi és Kaposvár lelőhelyeiről alapvetően háztartásokban, hétköznapi munkákban használatos vastárgyakat vizsgáltunk.

Az avaroknak a vasmüvesség teljes vertikumára kiterjedő szakmai ismeretéről bátran ki lehet jelenteni, hogy empirikus jellegű, valószínűleg generációról generációra öröklődő tudásuk, tapasztalatuk által minőségileg versenyképesek voltak az akkori európai technikai színvonallal és vasminőséggel. Ugyanakkor esetenként olyan speciális, aprólékos munkákhoz is felhasználtak vasat, mint amilyenek a nagyvenyimi, több fémböl összeállított övtartozékok (szíjvég, szíjveret), amelyeknek vas alapjára - igencsak különleges módon, alakítással, vágással, hevítéssel - ón-vassárgaréz kompozíciót dolgoztak ki, amelybe piciny vaskarikákat és vékony vashuzalokat is beledolgoztak. ${ }^{29}$

\section{Az avar vasmüvesség szakmai rendszere}

A tanulmány következő, több alfejezetből álló részében az a cél, hogy a rendelkezésre álló adatok alapján minél többet rekonstruáljunk az avar kori vasmúvesség, főleg a kovácsolás technológiáiból, szakmaszervezetéből és a tudásátadás módszereiből, amely által feltérképezhető lehet a szakmák gyakorlásának folyamata. Mivel ezek régészetileg nagyon nehezen megfogható momentumok, így párhuzamként az Árpád-kor, a középkor, a kísérleti régészet, valamint részben a néprajz forrásait használtuk fel (12. ábra). Végeredményként képet kaphatunk az avar kori vasművesség fejlettségéről, hatalmi szerepéről és jelentőségéről, szakmáinak konkrét vonásairól. A következő egységben tehát a „,Ki?", „,Mit?”, „,Hol?" és a „Hogyan?" kérdésekre keressük a választ

\section{A vasmüvesség és a vasmüvesek társadalmi megítélése}

Elsőként a,"Ki?" kérdéssel kell foglalkoznunk. Még mielőtt mélyebben elmerülnénk az avar vasas mesterek munkamódszereiben, lényeges szót ejteni arról, milyen szerepet töltöttek be a korabeli társadalomban. Magas szintű megbecsültségüket mi sem mutatja jobban, hogy a germánoknál, a rómaiaknál, a görögöknél és számos más népnél is létezett kovácsistenség. A magyaroknál is bizonyosan így volt, hiszen népmeséinkben is előfordul a mitikus kovácsisten, az Égi kovács vagy az Országkovácsa, akinek hajlékát vasfal veszi körül és a vasorrú bábát agyonkalapálja. ${ }^{30} \mathrm{~A}$ honfoglaló magyaroknál is megvolt a kovácsok vallásos tisztelete, olyannyira, hogy Alföldi András, Györffy György és Heckenast

29 TÖRÖK - KovÁCS 2015.

30 BOGdÁN 2006; GÖMÖRI 2010, 15.

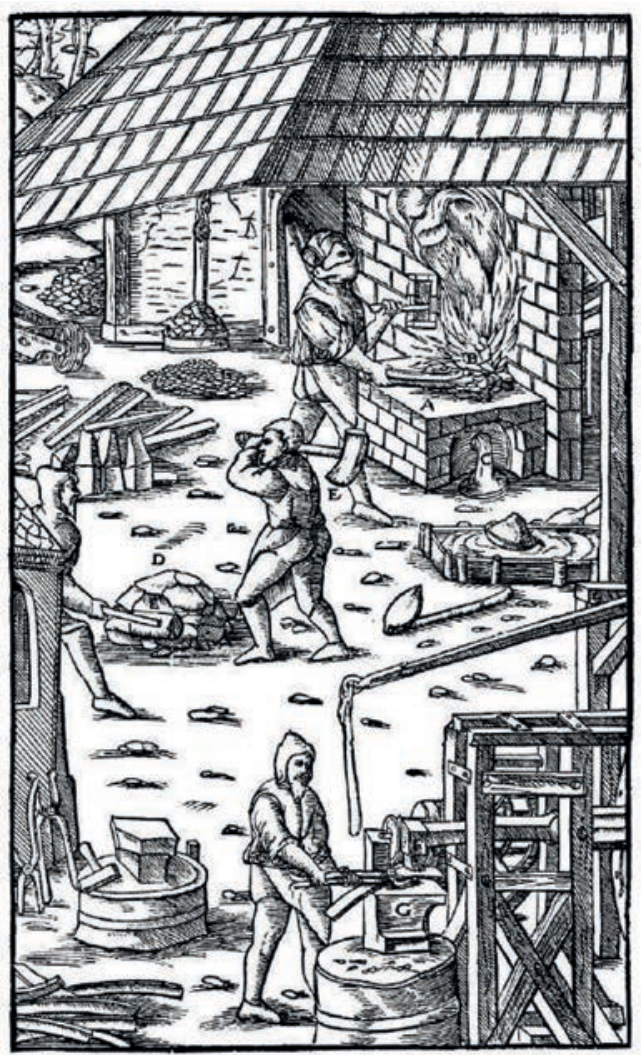

12. ábra. Bucakemence és vastörő a 16. században (AGRICOLA IX. könyv 220. ábra) 
Gusztáv szerint még a "tarchan" és a "kende" méltóságnév is szorosan összefügg a kovácsmesterséggel, amennyiben az ezeket a méltóságokat viselő személy az eredetmonda és a kovácsmítosz földi letéteményese volt. ${ }^{31} \mathrm{~A}$ kovácsmesterség fogalma szinte minden népnél, így az avaroknál is egybeolvadt a varázslással és az égi világgal. ${ }^{32} \mathrm{~A}$ vas előállításának nagy szakértelmet igénylő folyamata a közösség szemében szinte vallási szertartássá avatta a kovácsolás folyamatát, ismerőinek pedig misztikus erőt tulajdonított. Az ősi hit szerint a mester nem csak az anyagon, hanem az anyag szellemein is uralkodott, így nézhették mesterségét varázslásnak. ${ }^{33}$ Ezek a különleges emberek

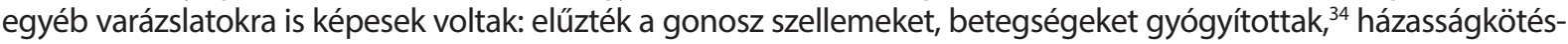
nél az ő közbenjárásuk is szavatolta a házasság sikerét. Bölcsességük, kiváló emberismeretük miatt gyakran működtek tanácsadóként is, sokfelé a falu eszének tartották őket. Tiszteletük viszont nem csak a vallásos gondolkodásból fakadt, hanem abból a fontos tényből, hogy olyan eszközöket voltak képesek az emberek kezébe adni, amelyekkel semmilyen más anyagból készült szerszám nem versenyezhetett. ${ }^{35} \mathrm{Nem}$ csoda tehát, hogy a kovácsokat, akik képesek voltak a teremtés és a pusztítás eszközeinek elóállítására, majdhogynem vallásos tisztelet övezte. ${ }^{36}$

Plinius tökéletesen összefoglalja az ember és a vas ellentmondásos viszonyát:, Az élet legjobb és legrosszabb eszköze a vas, amivel a földet szántjuk, cserjéket metszünk, a szölötőkéket évenként megfiatalítjuk a satnya hajtások visszavágásával, házakat építünk és köveket bányászunk vele és mindenféle más hasznos dologra is jó. Ugyanakkor háborúkra, gyilkosságokra és rablásra is használjuk, s nem csak közelről, hanem már sebesen repülő lövedékként is, melyeket hajítógépek vetnek ki vagy emberkéz röpíti őket, némelyiknek pedig valóban szárnyai vannak, amit az emberi elme legnagyobb gaztettének tartok, minthogy sebesebben repül a halál az ember felé, mióta szárnyakat készítettünk a vasnak. Ezért pedig az embert, és nem a természetet kell hibáztatni."137

\section{A kovácsmesterek jellemzői, a kovácsmesterség elsajátítása}

Továbbra is a „Ki?" kérdésnél maradva az égiek mellett foglalkoznunk kell természetesen a valódi kovácsokkal is. Egy 1693-ból fennmaradt forrás nagyon érzékletesen és képletesen mutatja be a kovácsot, mint embert. Ez a kép olyannyira állandó, hogy az avaroktól egészen az újkorig ilyennek képzelhetjük el a vasas mestereket:

„...Mellyek mint ha jöttek volna az Aetnábúl,
Vulcánusmivének szennyes barlangjábúl,
Most-is füst gözölög némellyik szájábúl,
Hatan álnak elö kovácsok számábúl.
Vas por szennye ülte hízott pofájokat,
Szenek pozdorjája füstölte nyakokat,
Sok szikra csipdeste fel-türött karokat,
Egy-egy pöröly telte bé-fogott markokat.
Ritkúlt a' szakállok csapdozó tüzekkel,
Éktelen homlokok pörsöllett szemekkel,
Orczájok varas súlt gyakor égésekkel,
Merő fél ördögök kormos személlyekkel.
De mint Óriások temérdek tagokkal,
Hegyeket birnának emelni vállokkal,
Labdaként jádczonak az ülö vasakkal,
Mindent végbe visznek erőss munkájokkal.
Száz font vasat adnak kezében ezeknek,
A'Kemény számára mellyet készittetnek,
Lábára illy gyenge láb szijjat füzetnek,
El-készitésében azok-is sietnek (...)"3s

31 GöMÖRI 2000a, 285. E hipotézist azonban ma már csak a kultúrtörténeti érdekességek közé sorolják.

32 Több kutató is felhívta a figyelmet arra az érdekes jelenségre, hogy a „kovács" és az „acél” szavaink szláv eredetűek. Felvetődik a kérdés, miért kellett idegen szót átvenni egy addigra hosszú múltra visszatekintő szakma nevére. Ennek magyarázata valószínúleg az, hogy a kovácsokat körülvevő vallásos tisztelet miatt az ún. tabu fogalmak, személyek és tárgyak kategóriájába tartoztak, ezért feltétlen szükség volt egy másik szóra, amivel jelölni lehet őket (BARTHA 1958, 325; HECKENAST 1966, 141).

33 A jakut közmondás szerint nem véletlen, hogy a "kovácsok és sámánok egy fészekből bújtak elö." (Gömörı 2000a, 284, 87. lj.)

34 Ez utóbbi képességük még az Árpád-korban is többé-kevésbé kiemelte a kovácsokat a jobbágyok közül (SzABó 1954, 124.).

35 BARTHA 1958, 321.

36 Ez a vallásos tisztelet azonban inkább csak a kovácsoknak szólt. A kohászoknak korántsem volt ekkora megbecsültsége, róluk nem emlékeznek meg a források (BoGDÁN 2006.). S rá példa, hogy a kovácsokat a rabszolgák közé sorolják, mint ahogy a burgundok törvénykönyve X. fejezetében szerepelnek (GöMörı 2000a, 284.).

37 Plinius XXXIV. 39.

38 GYöNGYÖsI 1693, I. 18-23. 
Ezt a különleges szakmát nem sajátíthatta el bárki. A kovácsolás mesterfogásai titokban, családon belül öröklődtek, amibe a gyógyítói gyakorlat is beletartozott. Ez annak következménye is volt, hogy a sokrétű mesterség munkáit gyakran családjukkal együtt végezték, azaz a gyermekek számára egyértelmű volt, hogy apjuk szakmáját folytatják. ${ }^{39}$ A kovácsokat akár messze földről is felkereshették (vagy ők maguk vándoroltak), ami azt jelenti egyúttal, hogy sok idegen emberrel találkozhattak. Látókörük ennek köszönhetően sokkal szélesebb volt, mint az átlagemberé, illetve kiváló emberismeretre is szert tehettek. Az ázsiai eredetű, nemzetségi, törzsi alapon szerveződött népeknél a kovács gyakorta látott el sámáni teendőket is. Egy beszédes csukcs eredetű szólás szerint: „Okos arca van ennek az embernek, mint egy kovácsnak.", vagy például egy jakut közmondás így szól: „,Kovácsok és sámánok egy fészekből bújtak elő". 40

\section{Az avar vasmüves- és kovácsmühely felszerelése, eszközkészlete}

Az eddig megismert kohász és a kovácsmester eszközkészletének szemügyre vételezéséhez a legegyszerủbb és legcélszerübb módszer egy jól felszerelt műhelyt a valóságban körbejárni. A következő megválaszolandó kérdésünk tehát a „Hol?".

A vas feldolgozásától általában távol, mint láttuk korábban, önálló vaskohó telepek kohóiban állítják elő a vasat. ${ }^{41} \mathrm{~A}$ kohászok közel sem használtak olyan változatos eszközkészletet, mint a kovácsok. Nekik elég volt egy fújtató a kohósítási folyamathoz, egy salakverő a vasbucán maradt salak leválasztásához, illetve egy vaskampó a buca kihúzásához. A vasat természetesen nem csak készíteni, hanem megvenni is lehetett (bár ez inkább a későbbi korszakokban jellemző), valamint a vas igen értékes mivoltából kifolyólag az eltörött, elkopott szerszámokat is be lehetett olvasztani, és újabb tárgyakká alakítani azokat. ${ }^{42}$

Mivel a régészeti korszakokban viszonylag ritkán fordul elő teljesen felszerelt kovácsmúhely, ezért néhány példát a kora újkorból és a néprajzból kölcsönöztünk (13. ábra). Az avar kovácsmühely általában félig földbemélyített, téglalap alakú épület. Mivel a kovácsmesterség igen tüzveszélyes, ezért a mühelyek a falvak szélén, ahol lehetőség volt rá, ott a patak vagy folyó mellett és feltehetően az út mellett helyezkedtek el. Az épület központi eleme a fújtatóval ellátott kovácstűzhely, amely jól megvilágított helyen kell, hogy legyen, hiszen így lehet jól nyomon követni a hevített vas színváltozásait. A kovácstűzhely egyik oldalán faszén, a másik oldalán valamilyen vízzel teli hűtővályú állt. A faszenet valószínűleg nagyobb időközökben égették, így a műhelyekben is sok szén lehetett felhalmozva. ${ }^{43} \mathrm{~A}$ falon különféle méretű fogók, kések, reszelők, fúrók és fenőkövek lóghattak. A tủzhelytől nem messze állt az üllő, amelynek helyét évszázados gyakorlat szabta meg. A tủzhelyhez közel kellett álljon, hogy az izzó vasat könnyedén odavihessék. Az üllő körül szabad helynek is lennie kellett, hogy a mester és a legénye könnyen mozoghassanak. ${ }^{44}$

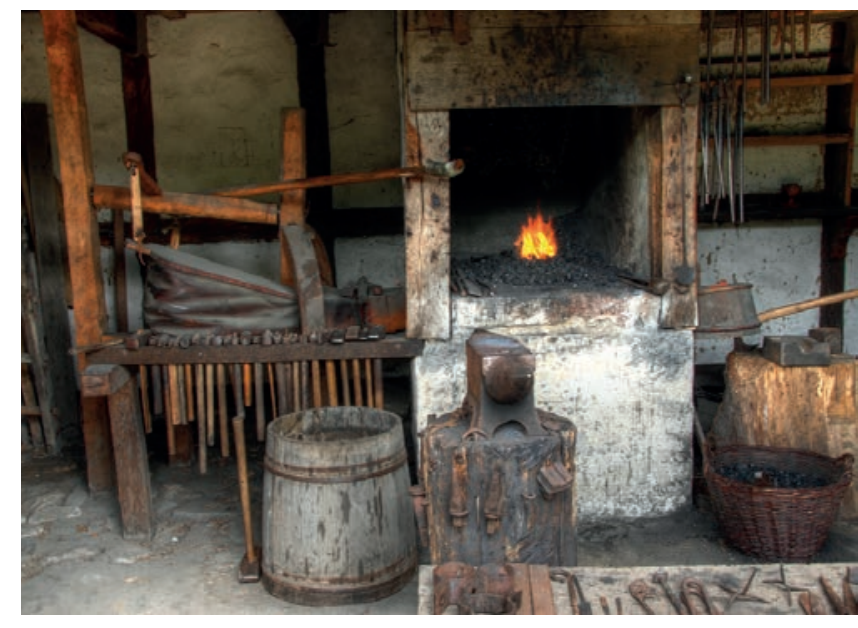

13. ábra. Kora újkori kovácsmühely Pankaszról (http:// www.aircontrolindustries.com/global/wp-content/ uploads/2014/06/blacksmith-bellows-forge.jpg

39 SzABó 1954, 123. Az apáról-fiúra szálló mesterségbeli hagyomány továbbélésére jó példa egy Maliból származó 1995-ben filmezett eset, ahol a falu melletti több száz éves romos kohótelepen még néha vasat állítanak elő. A vezető kohász a kohó tapasztási rétegeiből az 1700-as évekig visszamenőleg elmondta, hogy mikor melyik kohász dolgozott a kemencében, akik egymás leszármazottai voltak (GöMÖRI 2000a, 240, 87. lj.)

40 O. NAGY 1966,66

41 Az avar kohótelepeken lakóházak és kenyérsütő kemencék is előfordulnak, hogy az ott lakást és az élelmezést biztosítsák (GömöRı 2000a, 169.). Az Árpád-kor folyamán a vasasok nem laktak, csak működtek a vasműves telepek egy részén (GYöRfFY 1972, 284). Mivel a kohósítási folyamat rengeteg fát igényel, ezért célszerű volt a kohókat úgy felépíteni, hogy erdőhöz is közel legyenek (GömöRı $2000 b$, 221-245; GöMöRı 2000a, 66.). Meghatározó volt ugyanakkor a vasérclelőhely közelsége is.

42 Mi sem bizonyítja ezt jobban, hogy a középkor folyamán sok az elrejtett vasszerszám, illetve az elpusztult Árpád-kori házakban és műhelyekben alig vannak vastárgyak. Ugyanez a helyzet már az egykori római telepeken is, ahol a Kr. u. 3. század közepétől számolhatunk vasválsággal, ami takarékosságra kényszerítette a lakosságot (SzABó 1954, 124; NYULAs 2016, 59.).

43 SzABó 1954, 125.

44 Munka végeztével nem volt szabad az üllőn hagyni a kalapácsot, mert úgy tartották, hogy éjszaka az ördög dolgozik vele (AnDRÁSFALvY ET AL. 2001.). 
A késő avar korban már csak egy-egy szerszám fordul elő sírokban (például a zamárdi temető négy sírjában is). Ez, illetve egyes kovács- és ötvössírok alapján elképzelhető a gepida vagy langobard eredet is. Bár látnunk kell azt is, hogy az avar korban teljesedik ki a szerszám-mellékletadás szokása, ami párhuzamos szokás a presztízstárgyak sírokba kerülésével. ${ }^{45}$

Érdemes felsorolni milyen eszközöket, szerszámokat ismertek a fentiek alapján. A mérés eszközei: bizánci mérlegek, súlyok - ötvösök. Plasztikus alakítás: kalapácsok: nagy kovács, trébelő, kicsi ötvös, római típusú, kelta-germán eredetű hoszszúkás (14. ábra). Alátétek: egyengetőlapok, üllők. Rögzítő eszközök: fogók: lapos vagy kovács. Darabolók: lyukasztó. lemezvágó olló, vágóvas, hidegvágó. Forgácsolás szerszámai: vésők, árvésők, fűrész, reszelő, fúrók. Dróthúzó. Szegfejelő. Fenőkő, csiszolókő. Szorítóvas. Fúvócsövek - fújtatókról. ${ }^{46}$ A népvándorlás kori (germán, avar, lásd előző fejezetekben!) kovács- és ötvössírok alapján megállapítható, hogy az avar kovácsok jórészt a római, germán és a közelmúltig ismert kovácsműhelyek alapszerszám-készletével dolgoztak. E szerszámok az idők folyamán alig változtak. ${ }^{47}$

A fentebb bemutatott szerszámok többsége és összetétele inkább ötvösre vall, de kovácsszerszámok is szépszerével előfordulnak e temetkezésekben (Csákberény 323. és 369. sír, Kisújszállás, Kunszentmárton 1. sír, Kölked-Feketekapu B 80. sír

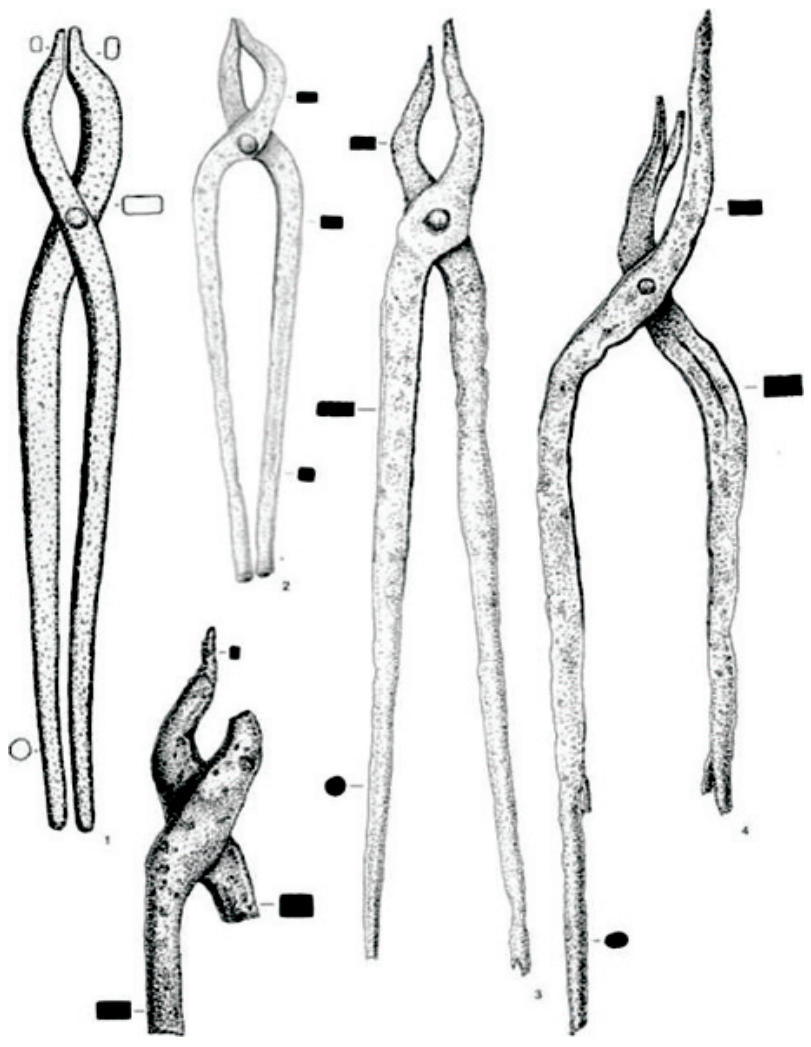

14. ábra. Avar kori fogók (RÁcz 2009, 79, 13. kép) stb.). Sokoldalú, egyszerre több tevékenységet is végző, ezermesterek képe rajzolódik ki előttünk. ${ }^{48}$

\section{A korabeli kovácsmesterség munkamódszerei}

Miután már tudjuk, hogy kik és hol készítették az avar korban a vasat, rátérhetünk a „Hogyan?"-ra. Nem csak az avaroknál, de az összes vizsgált korszakban a falvak egyik legnélkülözhetetlenebb iparosa a kovács volt. A fegyverek mellett használati eszközöket készített. ${ }^{49} \mathrm{Az}$ avar korban a kovácsoknak - és a falusi mestereknek egyébként még a középkorban is - minden szükséges tárgyat el kellett tudniuk készíteni.

A kohósítási eljárás során kinyert vasból már el lehetett kezdeni szerszámokat és/vagy fegyvereket készíteni. A kovácstüzet fújtatóval kell izzítani, és a falusi kovács gyakran, főleg a korábbi korszakokban - valószínűleg az avaroknál is - segédje nem lévén, arra kényszerült, hogy maga fújtasson az egyik kezével. Valószínűleg később éppen ezért tértek rá a lábbal való fújtatásra, de ez már jóval az avarok után történt meg. ${ }^{50} \mathrm{~A}$ kovácsolást a vörösizzáskor ${ }^{51}$ végzik az üllőn kalapáccsal, egészen a lehűlésig. A tűzhely felől álló mester tartotta fogójával az izzó fémet, és egy kisebb kalapács (félkézverő) apró ütéseivel irányítja a tanulót (legényt), aki egy hatalmas kalapáccsal (öregverővel) két kézzel nagy erejű ütéseket mér a vasra, miközben a mester „pengeti” az állandó rit-

45 Elképzelhető, hogy a sírokban nyugvó egyes mesterek germánok is lehettek. Ez a nagy dunántúli temetők esetében feltételezhető, pl.: Csákberény, Jutas, Kölked-Feketekapu, Tolna-Mözs, Szekszárd-Tószeg, Zamárdi, illetve Erdélyben Mezőbánd (ÓDOR - RÁCz 2011, 245-255.).

46 RÁCZ 2009, 69-96.

47 A fémművesség fázisai és eszközkészlete még a késő középkorban is hasonló az ércelőkészítéstől a vas megmunkálásáig (AGRICOLA 8-9. kÖnyv; PLeiner 2006, 30-45. kép).

48 Például a Kölked-Feketekapu B 80. sírjában nyugvó, szerszámai alapján, egyszerre lehetett fegyverkovács és ötvös is, de famegmunkálással is foglalkozott. A kunszentmártoni és csákberényi 369. sírban nyugvó egyszerre volt ötvös és kovács is. (RÁcz 2009, 89, 2. táblázat).

49 Andrásfalvy et al. 2001.

50 Szabó 1954, 132.

51 A kovácsolásra szánt darabok hőmérsékletét a mester szemrevételezéssel állapíthatta meg. Ha a kérdéses darab sötétbarna, akkor hőmérséklete $600^{\circ} \mathrm{C}$ körül van, ha cseresznyepiros, akkor $750^{\circ} \mathrm{C}$, ha világossárga, akkor $1050^{\circ} \mathrm{C}$, vagy ha vakító fehér, akkor több mint $1150^{\circ} \mathrm{C}$, és esetleg fennáll annak a veszélye, hogy elég (ANDRÁSFALVY ET. AL. 2001). 


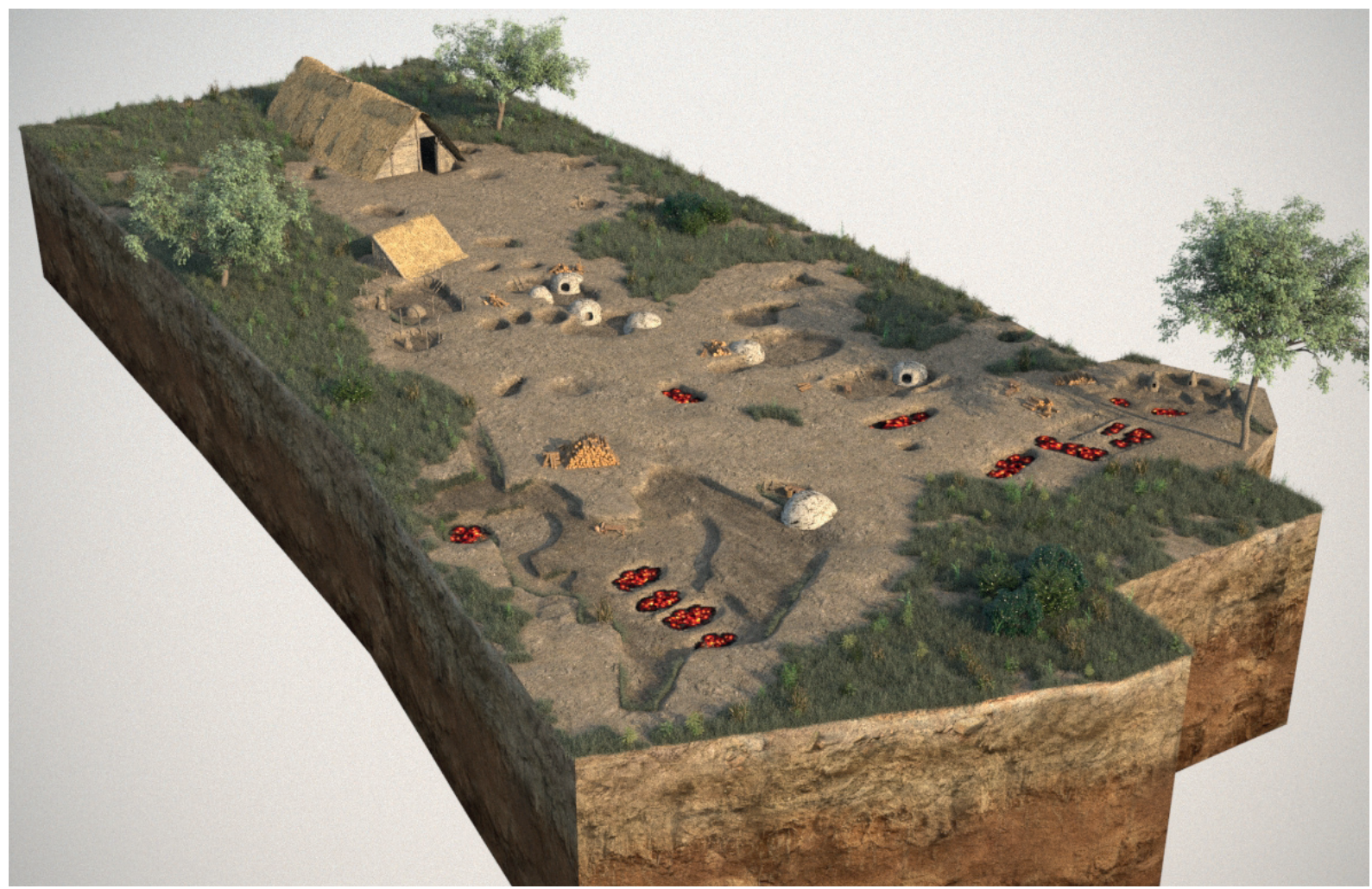

15. ábra: Zamárdi 89. lelöhely déli részének 3D-s rekonstrukciója (Készítette: Pazirik Kft. Gallina Zsolt instrukciói alapján)

must..$^{52} \mathrm{~A}$ kovácsoknak január-február, június, október és november hónapokban lehetett a legkevesebb munkája. A legtöbb pedig áprilisban, májusban, júliusban és szeptemberben volt. A nagy mezőgazdasági munkák idején volt rá leginkább szükség, hiszen a szerszámok elkophattak vagy eltörhettek. A kovácsok ilyenkor kora hajnaltól sötétedésig dolgoztak, akár két-három tanulóval is..$^{53}$

A kovácsmunka ilyenformán viszont időszakos jellegű volt, azaz előfordulhat, hogy mellette földeken gazdálkodtak, vagy kevéske állatállománnyal is rendelkeztek. Az orvosságok nagyobb részét ugyancsak a kovács készíthette, valamint alkalomadtán kisebb sebészeti mütéteket, például érvágást is végezhetett. Elképzelhető, hogy állatokat is gyógyítottak..$^{54} \mathrm{~A}$ háborús időkben nem voltak ilyen kiesések a munkából. ${ }^{55} \mathrm{~A}$ vasas mesterek egyedülálló tudása révén előfordult, hogy háborúk során gyakran foglyul ejtették, elhurcolták otthonról és máshol kényszerítették őket munkára. ${ }^{56}$

A vasmúvesség műhelyei, a technológiai fogások és a szerszámkészlet is nagyon hosszú időn át - a kora középkortól az újkorig -, és hatalmas területen, gyakorlatilag változatlan formában maradt fenn (16. ábra). Mindenhol igyekeztek a legnagyobb termelékenységú eljárásokat meghonosítani, a múhelyek és kohók formáját és a szerszámokat is a célszerűségnek megfelelően alakítani, hogy minél kisebb fáradtság árán állíthassák elő a vasat. ${ }^{57}$ Nagyon jól bizonyítja ezt például Gyöngyösi István korábban már említett munkája, amely tatár kovácsokról szól, de a kovács munkamódszerei olyan univerzális formában jelennek meg benne, hogy az tulajdonképpen bármely korszakra rávetíthető:

52 Ez a magyarázata annak is, hogy a középkori krónikákban a kovács munkája a ritmus és a ritmusosság jelképe is (SzABó 1954, 133.).

53 Érdemes felvázolni a 15. századtól a Kárpát-medencében is működő cigánykovácsok munkamenetét. Munkájukat egy hétre előre beosztották. Pénteken és szombaton beszerezték az alapanyagokat, vasárnap pedig előkészítették őket. Hétfőn megkezdődött a termelőmunka. Nyáron akár már hajnali kettőkor is elkezdhettek dolgozni, ha meleg volt, akkor tíz környékén abbahagyták, majd folytatták egészen este hét-nyolcig. Télen öt-hat óra körül kezdték meg a munkát. Hét elején akár napi tíz-tizenkét órát is dolgoztak, azért, hogy a hét végére több szabadidejük legyen. Elkészített termékeiket a hétvége folyamán eladták, vagy elszállították a megrendelöhöz (ANDRÁSFALVY ET AL. 2001.).

54 SzABÓ 1954, 136, 138-143.

55 ANDRÁSFALVY ET AL. 2001.

56 GÖMÖRI 2000a, 69.

57 BODGÁL 1968, 163-164; GÖMÖRI 2000a, 184. 


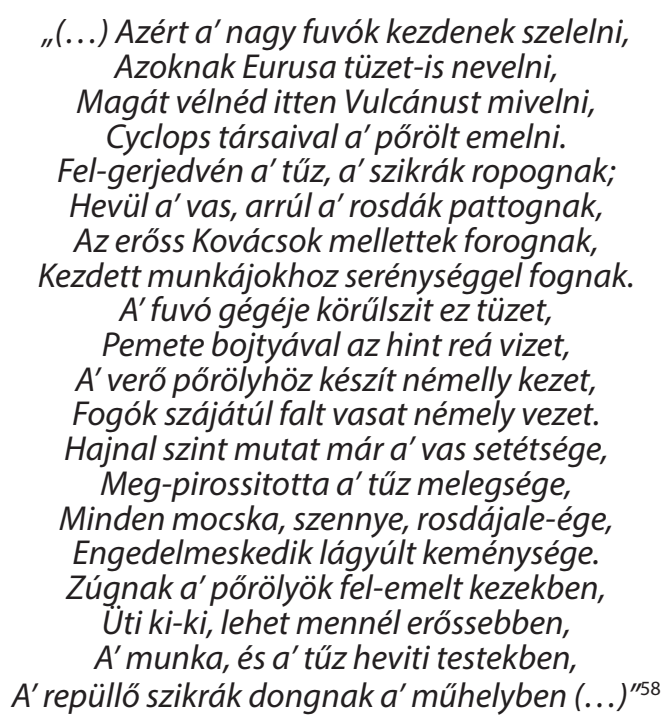

\section{A vasmüves települések társadalma és a szakma differenciálódása}

A vas előállítását a központi hatalom szervezte meg, ugyanis az ún. barbár munkaszervezés szorosabban kötődik a vezetőkhöz, azok birtokolják és dolgoztatják a kézmúveseket. A stratégiai fontosságú utak mentén létesített késő avar alvezéri szálláshelyek őrsége biztosította a termelés zavartalanságát és szállíthatta az eloaállított vasanyagot a felhasználási helyekre ${ }^{59}$ Gömöri János 2000-ben megjelent tanulmánya alapján 13 avar kori kohótelepet, 11 kovácsműhelyt és 8 salakmezőt ismerünk (15. ábra). ${ }^{60}$

Az eddigi fejezetekben már kitértünk a kovács- és a kohászmesterség szinte minden vizsgálható aspektusára. Mindössze annyi maradt hátra, hogy a „Hogyan" kérdésre megtaláljuk a választ. Milyen mértékben és hogyan osztották fel a vasmúvességgel foglalkozó emberek egymás között a munkát? Az avar korra vonatkozóan minimális forrással rendelkezünk a témát illetően, viszont itt is érvényes az a tendencia, miszerint a vasmúvesség olyan általános és állandó dolog, hogy nagy biztonsággal visszakövetkeztethetők egyes jellemzők későbbi korok adatai alapján is.

A vasmúves települések társadalmi rendszere és munkamegosztása hosszú évszázadokon keresztül alakult ki. A gyepvasérc kovácsvassá való alakításához a szénégetők, lóhajtók, gazdák, kohászok és kovácsok szoros együttmüködésére volt szükség. A szénégetők április végétől december elejéig kinn égették az erdőben a faszenet. Ez utóbbi múvelethez több ember munkájára volt szükség, a gödör megásásához, a boglya felrakásához és szétszedéséhez, valamint a kész faszén elszállításához. ${ }^{61} \mathrm{~A}$ lóhajtók a fát vontatták télen, valamint a gyepvasércet vagy a faszenet szállították a kohókhoz. ${ }^{22}$

Az előző fejezetekből megtudhattuk, hogy a feltárt kohótelepeken kis számban került elő kovácsmühely és késztermék, tehát a feldolgozást javarészt nem itt végezték, vagyis a kohótelepeken nem dolgoztak kovácsok. Ugyanez fordítva is igaz, a kovácsmühelyek környékén nem nagyon kerülnek elő kohók. Az avar korban a mai Dunántúl egyes régióiban (Somogy megye, Sopron környéke stb.) történt a vasgyártás. A kinyert és tömörített vasbucákat, esetleg rúddá kovácsolt félkésztermékeket kereskedelem útján értékesíthették, vagy központilag szállítmányozták a felhasználási helyekre, természetesen helyben is felhasználhatták (lásd Zamárdi). A településterület számos más helyén, lokális szinten megy végbe a késztermék feldolgozása, a kovácsolás. ${ }^{63}$ Kijelenthető, hogy az avar korban is jórészt elkülönül a kohász és a kovács szakma, mint a későbbi korokban is. ${ }^{64}$

Nagy kérdés az, hogy kovácsközpontok vagy falusi kovácsok működtek-e? Erre a kérdésre a rendelkezésünkre álló adatok alapján nem is tudunk válaszolni, de a szórványos adatok az utóbbira utalnak.

Mint láttuk a kora középkori (avar) kovácsnak sokféle vastárgyat kellett előállítania, a kovácsmunkák közül mindent el kellett végeznie. Nemhogy a kovácsolás minden fázisához, hanem a gyógyításhoz, sőt ritka esetekben még a kohászathoz is értenie kellett.

58 GYÖNGYÖSI1693, 23-27.

59 GÖMÖRI 2000a, 221-223, 34. lj.

60 GÖMÖRl 2000a, 222-223.

61 SZABÓ 1954, 125.

62 AndRÁsfalvy et al. 2001.

63 Gömöri János szerint a legkésőbbi, 9. századi avar kohótelepeken fordul elő inkább, hogy a kohók mellett kovácsmühely is van (Nemeskér stb.), ahol a fegyverek és hadi felszerelések készítése történhetett (Gömörı 2000a, 239-240, 278.). A távoli feldolgozásra jó példa a 2016-ban előkerült kecskeméti késő avar kovácsműhely (Wilhem Gábor és Gallina Zsolt feltárása, lásd fentebb!).

64 Jó példa az Árpád-kor folyamán fontos vasmúves központ, Sopron városa, ahol valószínüleg a várispán vagy az ő egyik megbízottjának felügyelete alatt állhatott a vas előállítása és gyártása is. A kohászok és kovácsok munkáját egy képzett vasiparos felügyelhette. A kohósítás során elöállított vastömbök (sínvasak) elöször egy központi raktárba kerülhettek, majd ezután adták tovább a kovácsoknak (GömöRı 2002, 111-112.). 
Felfedezhetjük a differenciálódás jeleit is. Ez a kovácsok és ötvösök kezdődő elkülönülésében is megjelenik, hiszen itt az alapanyag is más (vas, illetve arany, ezüst, bronz). Bár a sírokban a két szakma leletei gyakran együttesen fordulnak elő, ami arra is utalhat, hogy tulajdonosai a kovács és az ötvös szakmát, vagy annak bizonyos fajtáit együttesen is úzték. ${ }^{65} \mathrm{~A}$ korábbi korszakokban a rómaiaknál, a római kori barbár népeknél, szarmatáknál, langobardoknál, a gepidáknál és az avaroknál, úgy a honfoglaló magyaroknál is nagyobb számban kerülnek felszínre a vastárgyak mellett a bronz- és ezüsttárgyak is. Ez alapján a kovácsok mellett voltak ötvösséggel foglalkozó mesterek is. Az ilyetén elkülönülés a burjátoknál, mongoloknál, jakutoknál is létezik, mégpedig aszerint, hogy milyen fém megmunkálásával foglalkozik az adott mester: lehet "fekete” (vas) kovács és lehet "fehér" (ezüst) kovács. ${ }^{66}$

Mindenesetre bizonyos fokú "specializálódás" már az avar vasmúvesek között is lehetett, hiszen finomabb eszközök, nagyobb tárgyak, használati tárgyak, fegyverek elkészítéséhez más és más technológiát kellett alkalmazni. Számos eszközfajtát ismerünk föleg a már említett kovács- és ötvössírokból. Az archeometallurgia eredményei is sokrétú technológiai tudásra, számos fogásra világítottak rá, mely mind az egykori kovácsmesterség változatosságára utal. Az ismert sokféle vasminőség, a különféle előállított tárgy alapján azonban már felfedezhetjük a differenciálódás jeleit is. ${ }^{67}$

A honfoglalás korában már teljesen kettévált a kohász és a kovács mestersége. ${ }^{68} \mathrm{Az}$ ómagyar nyelvben a vasbuca elő́llítójának neve "vasas" volt, míg a kovácsé a "verő" vagy "vasverö. ${ }^{69}$ A pécsváradi apátság 1015-re keltezett (valójában a 13. században hamisított) alapítólevele is megkülönböztet „vasat szolgáltatókat” és „kovácsokat", ami szintén a vasfeldolgozás munkamegosztását bizonyítja. ${ }^{70} \mathrm{~A}$ kovács szakma valódi differenciálódása azonban csak a 13. században következett be, sem az avar korban, sem a honfoglalás korában nem lehetett szó ilyesmiről, innentől kezdve beszélhetünk kard- és késkovácsokról, lakatosokról, vagy üst- és lemezkovácsokról.11

\section{Konklúzió}

Minden korban igyekeztek vasat elóállítani, a nomádok is próbálták a szükségleteiket előállítani, ezért nem gondoljuk ezt egyfajta korai feudalizáció jelének. Láthattuk, hogy mindig szabadulni igyekeztek a vasbehozatal függésétől. Tanulmányunk során az avar kori vasmúvesség szakmagyakorlásának minden vizsgálható részletét megpróbáltuk bemutatni. Természetesen minden kérdésünkre nem kaptunk választ, bőven maradtak még fehér és homályos foltok.

Az avar vasmüvesség szakmai rendszerének vizsgálata rávilágított, hogy ez így önmagában, mint célkitűzés, részben nagyon nehezen, részben nagyon könnyen megfejthető. A fémművesség mind az azt végző emberekre, mind eljárásokra, mind eszközökre vonatkozóan olyan hosszú időn át változatlan formában létezik, hogy még késő középkori vagy akár kora újkori viszonyokban is megtalálhatjuk az egykori avar jellemzőket. Éppen ezért számos későbbi és néprajzi párhuzammal dolgozhattunk, ami minden eddiginél részletesebben tárta fel az egykori mesterek életét és munkáját (16. ábra).

A végső választ, reményeink szerint, az avar vasművesség feldolgozása és teljes rekonstrukciója adja meg.

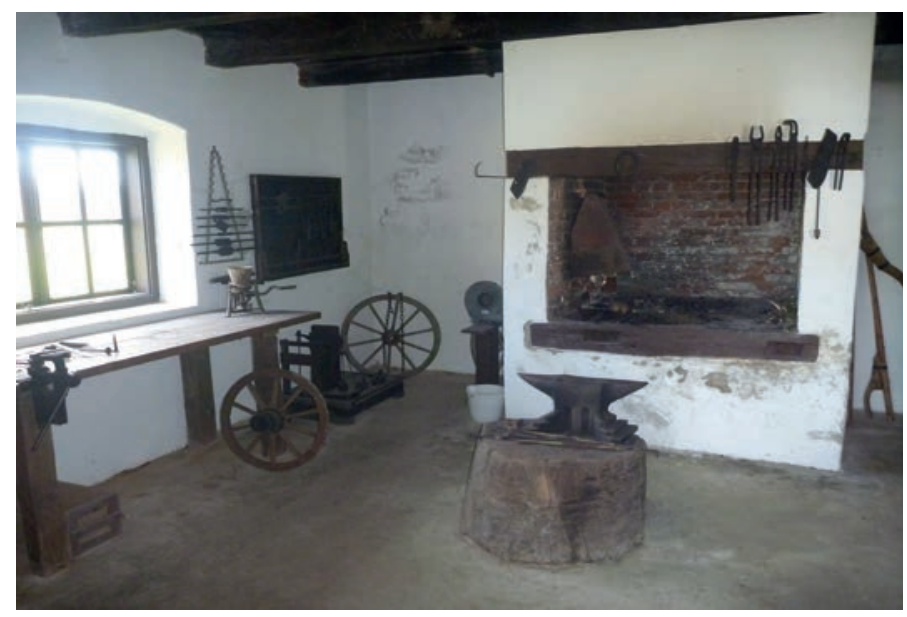

16. ábra. 19. századi kovácsmühely az Őrségböl, Nagyrákos (Fotó: Gallina Zsolt)

65 RÁCZ 2009, 67-96.

66 BARTHA 1958, 321-322.

67 A szerszámmellékletes sírok leletei alapján például a Kölked-Feketekapu B temető 80. sírjában páncélkovács nyugodott (RÁcz 2009, 88-89.).

68 GYörFFY 1972, 280.

69 Heckenast szerint az ugor korszak utolsó századaiban ismerkedhettek meg a magyarok a vasművességgel. Valószínűleg Baskíriában, majd Dél-Oroszországban is saját maguknak készítették fegyvereiket (HECKENAST 1966, 139.). A honfoglalás korában Liutprand forrása jegyzi meg, hogy 899-ben a magyarok egész télen fegyvereket és nyilakat készítettek (LIUTPRAND II, 8).

70 Ez a forrás a 11-12. századi állapotokat mutatja és nem a honfoglalás korát.

71 Céhszervezeteik is ekkortól kezdve voltak, de általában a városi polgárság alsóbb rétegéhez tartoztak, ritkán kerülhettek be a városi tanácsokba vagy a bírói székbe (SzABÓ 1954, 123.). 


\title{
The smith's craft and the work processes of Avar-period ironworking
}

\author{
ZSOLT GALLINA - BÉLA TÖRÖK
}

The goal of this study is to offer a broad outline of the craft organisation of the period's ironworking, principally of the high social prestige of smiths, of how smithing skills were mastered and how they were employed, as well as of the society of Avar-period ironworking settlements.

Described here are the crafts involved in Avar-period ironworking, the successive phases of the period's smelting procedures and the salient traits of the smith's craft. We essentially sought an answer to questions of "who?", "what?", "where?" and "how?", in the hope of reconstructing the work processes of ironworking, based on the organisation of smithing and the ironworking techniques. We also looked at the archaeological, experimental archaeological, archaeometric, historic and ethnographic aspects of smithing. We could demonstrate that smelters and smiths, the latter enjoying high social prestige, were separate crafts during the Avar period. In other words, iron was produced in a different location than where it was later processed and used. We were also able to identify rudimentary signs of differentiation among the various smithing crafts of the Avar period.

Obviously, we did not gain an answer to each and every question, and there remain several blank and unclear spots. The study of the craft organisation of Avar-period ironworking has demonstrated that some issues can be resolved fairly easily, while others with greater difficulty. Ironworking remained essentially unchanged for long centuries regarding the craftsmen engaged in this craft, the employed procedures and the tools, to the extent that the characteristic traits of Avar-period ironworking can also be detected in the late Middle Ages and the Early Modern Age. We could therefore draw from much later parallels and ethnographic sources, which enabled a considerably more detailed reconstruction of the life and work of the period's craftsmen.

We expect to gain conclusive answers to our questions following the meticulous assessment of the evidence on Avar-period ironworking and the reconstruction of its organisation.

\section{Irodalom}

AGRICOLA Agricola, Georgius: De re metallica Libri XII (Tizenkét könyv a bányászatról és kohászatról, 1556). Budapest, é.n.

AndRAsfalvy et AL. 2001 Andrásfalvy Bertalan - Balassa Iván - Égető Melinda - Gráfik Imre - Gunda Béla - Kotics József Paládi-Kovács Attila - Petercsák Tivadar - Selmeczi Kovács András - Solymos Ede - Szabadfalvi János - Szilágyi Miklós (szerk.): Magyar néprajz. Budapest, 2001.

BARKóCZY et AL. 2017 Barkóczy, Péter - Török, Béla - Kovács, Árpád - Molnár, István: How it's made - ARGUM's practice and methodology used for metallographic analysis of medieval iron artefacts from the Carpathian Basin Iron in Archaeology. Bloomery smelters and blacksmiths in Europe and beyond. International Conference in Prague, 2017, 30th May - 1st June. Abstract and poster.

BARTHA 1958 Bartha Antal: Honfoglaláskori kovácsmesterségünkről. Történelmi Szemle 1. 315-327.

BoGDÁN 2006 Bogdán István: Régi magyar mesterségek. Budapest, 2006.

BodGÁL 1968 Bodgál Ferenc: A kovácsmesterség kutatása. A Herman Ottó Múzeum Évkönyve 7. 157-165.

Czövek 2010 Czövek Attila: Avar kori kohótelep Bátaszék határában. A Wosinsky Mór Megyei Múzeum Évkönyve 32. $213-241$.

GaLıINA 2002 Gallina Zsolt: Avar kori kohótelep Kaposvár-Fészerlakon. Somogyi Múzeumok Közleményei 15. 75-85.

Galuina 2011 Gallina Zsolt: Avar kori vaskohászati és települési centrum Zamárdiban. In: Somogyvári Ágnes - V. Székely György (szerk.): A Barbaricum ösvényein. A 2005-ben Kecskeméten tartott tudományos konferencia elöadásai. Konferenciakötet. Archaeologia Cumanica 1. 179-198.

Galuina - Hornok - Somogy 2007 Gallina Zsolt - Hornok Péter - Somogyi Krisztina: Előzetes jelentés a Zamárdi, Zamárdit elkerülő 65101. sz. út 89., 58/a., 58/b., 56. lelőhelyeinek feltárásáról. Somogyi Múzeumok Közleményei 17/A. 153-168.

GömöRI 2000a Gömöri János: Az avar kori és Árpád-kori vaskohászat régészeti emlékei Pannóniában. Magyarország iparrégészeti lelőhelykatasztere I. Vasművesség. Sopron, 2000.

GömöRI 2000b Gömöri János: Azavar koriésX-XI. századivaskohászat régészeti emlékei Somogy megyében (The archaeological sites of county Somogy in the Avar and early Árpád-period). Somogyi Múzeumok Közleményei 14. 163-218.

GöMÖRI 2002 Gömöri János: Castrum Supron. Sopron vára és környéke az Árpád-korban (Die Burg von Sopron (Ödenburg) und deren Umgebungin der Árpádenzeit. The Castle of Sopron and its County in the Árpád-age $\left(11^{\text {th }}-13^{\text {th }}\right.$ cent. A. D.). Sopron, 2002. 
GöMÖRI 2009 Gömöri János: Égi és földi kovács. In: Nagy Zoltán - Szulovszky János (szerk.): A vasmüvesség évezredei a Kárpátmedencében. Szombathely, 2009. 7-16.

GYöNGYösı 1693 Gyöngyösi István: Kemény János emlékezete (Porábúl meg-éledett phoenix) http://mek.oszk.hu/06100/ 06118/06118.htm\#2 (letöltés: 2018. január 22.)

GYörfFY 1972 Györffy György: Az Árpád-kori szolgálónépek kérdéséhez. Történelmi Szemle 3-4. 261-320.

HeCKENAST 1966 Heckenast Gusztáv: A kora Árpád-kori magyar vaskohászat. Történelmi Szemle 9. 135-161.

HECKENAST ET AL. 1968 Heckenast Gusztáv - Nováki Gyula - Vastagh Gábor - Zoltay Endre: A magyarországi vaskohászat története a korai középkorban. Budapest, 1968.

LÁszló 1997 László Gyula: A honfoglaló magyar nép élete. Budapest, 1977.

LIUTPRAND Liutprand: Antapodosis. (ford.: Horváth János). In: Györffy György: A magyarok elödeiröl és a honfoglalásról. Kortársak és krónikások kiadásai. Budapest, 1975. 223-233.

NYuLAs 2016 Nyulas Dorottya: Vaskohászat és vasmegmunkálás a Római Birodalomban és Dáciában: rövid áttekintés. Történelem és Muzeológia - Internetes Folyóirat Miskolcon 3. 51-59.

O. NAGY 1966 O. Nagy Gábor: Magyar szólások és közmondások. Budapest, 1966.

ÓDOR - RÁcz 2011 Ódor János Gábor - Rácz Zsófia: Szerszámmellékletes sír a szekszárd-tószegi-dűlői avar temetőből. $A$ Móra Ferenc Múzeum Évkönyve - Studia Archaeologica 12. 245-255.

Pleiner 2000 Pleiner, Radomir: Iron In Archaeology - The European Bloomery Smelters. Praha, 2000.

PLEINER 2006 Pleiner, Radomir: Iron In Archaeology - Early European Blacksmith. Praha, 2006.

PuInIus C. Plinius Secundus: A természet históriája. Válogatott részek az I-VI. könyvekből. Csillagászati és földrajzi ismeretek az ókorban (ford.: Váczy Kálmán). Budapest, 1973.

RÁcz 2009 Rácz Zsófia: Avar kori ötvös- és kovácsszerszámok. In: Nagy Zoltán - Szulovszky János (szerk.): A vasművesség évezredei a Kárpát-medencében. Szombathely, 2009. 67-96.

SzABÓ 1954 Szabó György: A falusi kovács a XV-XVI. században. Folia Archaeologica 6. 123-145.

Török 1999 Török, Béla: About the Technical Investigations of Ore, Slag and Wall-fragment Samples Found Next to the Sites of Nemeskér-type Furnaces. Nemeskéri típusú vasolvasztó kemencék lelőhelyén talált ércek, salakok és kemencefal-darab műszaki vizsgálatai. In: Gömöri János (szerk.): Traditions and innovations in the early medieval iron production. Hagyományok és újítások a korai középkori vaskohászatban. Sopron-Somogyfajsz, 1999. 160-169.

Töвöк 2010 Török Béla: Árpád-kori vaskohászati műhelyek metallurgiája a műszaki vizsgálatok tükrében. Gesta IX. $227-232$.

Töвöк 2011 Török Béla: Vasérc, vasbuca, vastárgy. Az első magyar vaskohászok műhelyei és technikája a Kárpát-medencében. Bányászattörténeti Közlemények XII. 6/2.3-29.

TöRÖK - KovÁcs 2009 Török Béla - Kovács Árpád: Avar vastárgyleletek szövetszerkezetének elektronmikroszkópos vizsgálata. Examinations of metallographic structure of Avar iron finds by electron microscope. XI. Bányászati, Kohászati és Földtani Konferencia kiadványa. Máramarossziget, 2009. 91-95.

TöRÖK - KovÁCs 2011 Török, Béla - Kovács, Árpád: Materials Characterization of Iron and Slag Finds of the Early Medieval Avar Metallurgists. Proceedings of the $15^{\text {th }}$ International Metallurgy \& Materials Congress (11-13 November 2010). Istanbul, 2011. 386-397.

TöRÖK - KovÁcs 2015 Török Béla - Kovács Árpád: Nagyvenyim-Munkácsy utca - Fűzfa utca lelőhelyen talált vas és bronz övtartozékok elektronmikroszkópos archeometriai anyagvizsgálata. Alba Regia, C sorozat 43. 65-73.

TöröK - GalLINA - KovÁcs 2015 Török, Béla - Gallina, Zsolt - Kovács, Árpád: Iron metallurgy of the Pannonian Avars of the 7-9 th century based on excavations and material examinations. Der Anschnitt 26. 229-237.

TÖRÖK - KovÁCS - SzüCSI 2016 Török Béla - Kovács Árpád - Szücsi Frigyes: Előszállás-Öreghegy és Úrhida-Arany János utca lelőhelyeken feltárt avar kori fokosok elektronmikroszkópos archeometriai anyagvizsgálata és régészeti értékelése. Alba Regia, C sorozat 44. 17-36.

Török ET AL. 2018 Török Béla - Barkóczy Péter - Kovács Árpád - Költő László - Fehér András - Szőke Béla Miklós: Pannóniai kora középkori ékelt vasbucák összehasonlító archeometriai vizsgálata - A comparative archaeometric study of early medieval split blooms from Pannonia. Bányászati és Kohászat Lapok, Kohászat 151/3. 1-4. 
